\title{
From slavery to indenture: scripts for slavery's endings
}

\section{Anita Rupprecht}

Having arrived in Jamaica as one of the Special Magistrates sent from England to oversee the passing of the 1833 Emancipation Act, Richard Madden observed that, the late change which has taken place in the condition of the negro population of these islands, must necessarily lead to great alterations in the mode of managing plantations. It requires as little knowledge of human nature, as of political economy, to be assured that no man will labour without reward, who can avoid it. Hitherto, coercion was necessarily employed to obtain labour; but the new law, in making coercion the legal penalty of its infraction, instead of an arbitrary punishment, summarily inflicted, has deprived it of the character which chiefly constituted its terrors; for nothing, I apprehend, can be more productive of terror than the power of inflicting punishment in the heat of passion. That stimulus to labour is therefore in the hands of the special justice, not what it was in those of the overseer. In some cases in four years, in others in six years, it will not exist at all. In the intermediate time conciliation, to a great extent must be looked to, to effect what coercion formerly did. ${ }^{1}$

Madden's reflections function as a vivid reminder of the ways in which instrumental economic imperative, imperial interest, and colonial fantasies about appropriate colonial subjectivity framed official interpretations of slave emancipation. If 'freedom' was something to be bequeathed in such a way that labour productivity would continue uninterrupted, a key question concerned the relocation of the 
'stimulus to labour'. If the arbitrary forms of terror associated with a privately-owned labour force had previously ensured steady work, now - and until such time as it was no longer required - it would be secured institutionally, through a penal framework administered by colonial agents. The 'great change' that would nevertheless ensure productive continuity was thus to be achieved by the imperial state taking over the direction of labour. During the period of state-administered labour discipline, or 'apprenticeship', Madden supposes that sentiment will play its part. The fact that he notes that a conciliation needs to be secured in order for the Caribbean plantations to survive and prosper perhaps hints at a long-held colonial anxiety that perhaps things might not work out.

Perhaps unexpectedly, Madden's reflections about a possible conciliation between masters and workers leads him to eulogise about the success of Mathew Lewis's so-called enlightened plantership in 1815 and 1817 instead of any earlier experiment in 'freeing' the enslaved. Lewis had (reluctantly) inherited two plantations, and he when he arrived in Jamaica in 1815 he found his properties in disarray, and his six hundred slaves on the verge of rebellion. According to his account of his experience, he spent his time, and definitely extremely nervously, attempting to re-establish his paternalistic sovereignty over his bondsmen and women. Like so many other colonial reformers, he cast the project of reinforcing labour hierarchies as an effort in 'conciliation' between himself and his workforce. He developed management techniques that were designed to restore productive order by eliciting the appropriately subordinating sentiments of his labourers: gratitude, contentment, and dutiful loyalty. Lewis introduced a system of petty rewards, abolished the use of the whip in the field, and the flogging of enslaved women, allowing Saturdays as free time, and instituted an annual 'royal holiday'. ${ }^{2}$ The 
ameliorative measures seemed to have been successful as Madden reports that Lewis's heir, his nephew, has recently confirmed that the plantations are now flourishing amongst so many others that have gone to the wall. As a result, Madden enthusiastically pronounces, 'By [Lewis's] two visits he saved his properties!'

Thus, at the moment of emancipation, Madden looks back in order to look forward, rehabilitating Lewis (who had never countenanced freeing his slaves) as a canny proprietor, sovereign protector, and as an exemplary authority on, or an innovator in, labour management. His exclamation - as an avowed anti-slavery supporter and committed (if albeit institutionalised) activist who was to become a fierce and effective critic of the apprenticeship arrangements - resonates across the history of the abolition campaigns for a variety of reasons that are central to this chapter. Firstly, it is a reminder that, for the elite abolitionists, the arguments for ending slavery was almost always framed with a goal of maintaining the colonial plantation complex. Secondly, it registers the importance of continuing labour discipline to both abolitionists and planters. Thirdly, it identifies the particular terms within which abolitionists took up the argument for 'free labour' as offered theoretically by political economy and which Madden takes for granted as a certain form of 'common sense'. ${ }^{3}$

The nature, extent, and wider impact of the analysis of slavery embedded in late eighteenth and early nineteenth century classical political-economic writings have been subjects of recent debate amongst critics and historians. ${ }^{4}$ The apparent dearth of sustained attention to the fact that a peculiarly modern form of slavery was flourishing in the very belly of commercial society has been explained as an effect of the vigorously progressive thrust of the political economic narrative. As Walter Johnson notes, it is possible to generalise to the point at which one can say that 'bourgeois' 
theories of political economy get off the ground through the foundational erasure of slavery because within their enlightened terms, slavery is, or should be, in some senses no longer thinkable. ${ }^{5}$

Seymour Drescher adopts this view to argue that the limited, and ambivalent, discussion of slavery within the 'new science' meant that British abolitionism, in its search for outside authority, had found little of substance, or indeed of comfort, when formulating their campaigning arguments. ${ }^{6}$ That the 'free labour' argument remained muted amongst abolitionists stands if one tracks, as Drescher does, the fate of the most arresting axiom to do with the deployment of 'labour', articulated most famously by Adam Smith, as 'the work done by freemen comes cheaper in the end than that performed by slaves'. ${ }^{7}$ Abolitionists were indeed vulnerable when the axiom was mobilised in contexts that were either too particular or too general. On the one hand, in the cut and thrust of heated debate, both sides often reverted to the reductive idea that theoretical statement could be proved or disproved by contingent empirical evidence, most often at the abolitionist's cost. On the other, the axiom was prone to losing the vital (and temporally ambiguous) Smithian qualifier of 'in the end', becoming an indefensibly sweeping assertion about the relative cheapness of two, historically unnuanced, forms of labour. On this basis, a discrete focus on the debate about the relative cheapness of 'free' or enslaved labour, as it waxed and waned from the 1780s through to the Emancipation Act, risks suggesting that when abolitionists championed the 'efficiency' and cheapness of so-called 'free labour' they were often simply mistaken, or that they were somehow insincere because they knew that they could not refute the empirical evidence, or that the argument about 'free labour' was less important to them than it sometimes appears. In this respect, Drescher's detailed analysis of a discrete set of economic ideas about the stubborn profitability of 
enslaved colonial labour, articulated at times by a limited number of abolitionists, readily supports his larger project of understanding abolition as a national 'econocide' committed in the name of moral humanitarianism.

Drescher's terms of the analysis obscure as much as they reveal, however, insofar as to focus on the role of Smith's oft-repeated statement captures only one aspect of abolitionism's shifting identification with political economy and its wider implications. Moreover, one of the consequences of the approach is to reduce the contingent historical processes by which the boundaries between different forms of labour could be drawn and redrawn, as well as the historical specificity of the ways in which the concepts of enslaved labour and 'free labour' were mobilised and understood, to particular, and different, contexts.

Smith himself never doubted that the use of enslaved labour was profitable in the narrow sense of increasing the wealth of those who could arbitrarily exploit the weak with impunity. The reason why he was so interested in the issue was because it telegraphed the grander distinctions between self-interest and selfishness, liberty and license, and between natural markets and artificial ones. That is, it cut to the heart of his all-embracing theory of political economy founded on a theory of enlightened human nature. The problem with monopolies and slavery was that they contravened the natural link between freedom, self-interest and economic progress. Like Hume, Smith portrayed these abuses as harmful not simply because they were inefficient indeed this problem did not seem to exist on the balance sheet of the slave-owner or the monopolist - but more importantly because they distorted the flow of goods and services in ways that hindered the long-term growth of the economy more generally.

Smith noted that there was something 'peculiar' about the tropical nonessential goods of tobacco, and especially sugar, but his criticism of the West India 
planters reflects his more general attack, in The Wealth of Nations, on the propensities of merchants. Their monopolistic activities not only disrupt competitive price mechanisms, they also have deleterious effects on a merchant's 'character', and hence, importantly, on the characters of labourers. ${ }^{8}$ For Smith, the most 'fatal' effect of vastly inflated mercantile profits is to destroy the (otherwise 'natural') 'parsimony' of the merchant who, as a necessary leader and 'conductor of industry' ... 'has a much greater influence upon the manners of the whole industrious part' of every nation. ${ }^{9}$ That is to say, Smith's comments are set within his all-embracing attack on the mercantile system: political economy, the study of the appropriate stabilisation of labour hierarchies in a commercial society, and moral sentiment, the philosophical reflection on the requisites of civility, are threaded through each other, and it is these issues rather than in an abstractly economic, or discretely financial, argument that energised and emboldened the early anti-slavery activists.

From the very beginning, the condemnation of slavery was accompanied by imagining alternative forms of labour. As Christopher Brown has detailed, well before the formalisation of an anti-slave trade campaign, more elaborate plans had been developed that justified ending slavery with an eye to ensuring the continuing viability of the industrial plantation complex. ${ }^{10}$ By the 1780 s, the two most influential abolitionist writers, James Ramsey and Thomas Clarkson, drew heavily on Smith's wide-ranging, anti-mercantilist agenda in order to propose, not simply reforming Caribbean labour practices, but a reformation of the entire colonial system.

Ramsey reflected Smith's attention to the damage caused by unregulated labour relations when he attacked the political-economic foundation of the sugar industry. He argued that the 'monopoly of the British market' had created a particularly cruel group of planters because the high returns enabled absenteeism and 
luxurious life-styles in the metropole. Because English planters were unrestrained by legal regulation, they were blind to the fact that their 'true interest was on the side of liberty, and of moral improvement, not in niggardly pinching, not in stripes, chains, and nakedness'. ${ }^{11}$

As Ryden notes, 'in so many words Ramsey was putting forward a free-labour argument' insofar as it would be cheaper and more efficient in a context free of Government subsidy and planter protection. $^{12}$ By ending the slave trade, and promoting civilization in Africa, new advantageous trading opportunities would develop, while planters in the West Indies would be forced to reform themselves as a result of new market discipline. Ramsey's Smithian arguments had a significant impact on the development of abolitionist rhetoric, especially on Thomas Clarkson who adopted the vision for a reformed Empire. Clarkson also highlighted the relationship between excessive mercantile wealth and deformations of character, arguing that planters should be compelled into more humane management. The efficiency of the slave trade meant that planters could work slaves to death, having no cause to nurture a natural population growth on their plantations. Not only was this utterly inhumane but the chasing of short-term profits had long-term negative effects on planters' wealth. Clarkson also had a grand vision for the colonial system that included highlighting the alternative benefits of redirecting British shipping, and crucially from the economic development of Africa. ${ }^{13}$ For both men, the questions of why slavery persisted out of sight across the Atlantic, and of how it might be replaced successfully, i.e. profitably, by free labour, were to be answered by the long progressive arm of political economy, as it embraced, at this stage at least, psychology, morality, and geography.

As Ramsey and Clarkson's founding documents attest, that long progressive 
arm was spatial but also temporal. The critique of slavery offered by the 'science of man' was embedded in a theory of historical development that saw slavery as a block to the economic logic of that development's onward march. What was novel about the new approach, as Shilliam notes, was that slavery's immorality was now conceived as a problem to be dealt with through the lexicon of commerce rather than common law. The shift changed the terms of the argument. Thus, for James Stuert, forced labour was a problem because it constrained wants. ${ }^{14}$ Similarly, Smith argued that, under slavery, human self-interest could not be activated under conditions of enslavement because workers derived no direct benefit from their own labour. As an inevitable result, they were less productive, and could only be governed by violence. These new, commercially oriented, assumptions, based on an enlightened understanding of the contours of universal human nature, helped to lever the so-called efficiency of free labour into a progressive theory of history but this did not necessarily mean that Scottish thinkers thought slavery's endings would be the inevitable outcome of historical advance.

Neither Smith, nor other writers of the Scottish Enlightenment, thought that slavery would disappear due to altered economic forces alone. On the basis of European exceptionality, slavery would continue to flourish unless political forces intervened directly to outlaw or dismantle it. Ramsey and Clarkson's plans, however visionary, also paid close attention to the legal developments that would be necessary for a transformation of the terms of colonial production; the view remained central to the different and contingent scripts for how slavery could be ended, and the plantations secured, as Richard Madden's view of emancipation in 1833 makes clear.

If political intervention was required to steer the grand narrative of developmental history, the necessary re-fashioning of its various subjects was also at 
issue. Smith had famously grounded his entire system on the idea that humanity was universally possessed of an innate capacity to truck, barter and exchange. But the kind of 'freedoms' conceptualised by the founding assumption did not easily capture the requirements made of enslaved colonial workers, who were most often conceived as a particular category of 'labour' rather than as individual agents. The famous 'invisible hand' of the market might have informed early plans for reforming the empire but that argument was conceived by Smith as part of his anti-colonial vision of the benefits of the freedom of commerce. It was to emerge again in the final emancipation debates but political economy did not offer much comfort for elite abolitionists who were thinking and arguing within the frame of 'actually existing empire' at the beginning of the nineteenth century.

On the other hand, the developmental narrative helped to open up a space within which economic considerations justified the construction of colonial, cultural or racial inadequacy, and through which the coercion that underlay the discourse of freedom and reform could be glossed. Thus Africans and their Caribbean descendants could be viewed as incapable, or at least not yet capable, of participating fully in the economic revolution that was happening around them. This intellectual space was exploited by elite abolitionists who did not often argue from biological flaw but almost always from matters of errant, or uneven, history. Habits, attitudes, and social practices, understood to be antithetical to supporting a 'free' labour regime, were interpreted as the result of African ignorance and barbarity combined with generations of brutalizing enslavement.

Thus the commitment to the promise of cheaper labour was inextricably bound to the question of labour discipline. ${ }^{15}$ The problem of plantation management - the problem of producing self-dependence and loyal servitude - exercised pro-slavery 
supporters, anti-slavery advocates, and the Colonial Office. How could a selfdisciplined and self-reproducing labour force be created, one with the capacity to work willingly for someone else not simply as a matter of survival but in the belief that it was in their self-interest so to do? Abolitionists were thus deeply invested in the promise of political economy insofar as they took its universal humanism as their starting point. They were always interested in the internal dynamic, and character, of human motivation, the very basis of the Smithian argument, rather than simply being engaged with the nature of macroeconomic re-distribution. To note that abolitionists tended to put their number-crunching at the back of their campaigning pamphlets, underplays its intimate relationship to what filled so many pages at the front. ${ }^{16}$ Here, they devoted endless attention to identifying the 'stimulus to labour' under different conditions, and to providing ways of calibrating degrees of freedom and unfreedom so that colonial productivity could be preserved.

It is perhaps ironic that, by taking up this aspect of political economy, abolitionism brought the question of slave agency to the forefront. ${ }^{17}$ By paying attention to the historical context within which the political-economic arguments about the necessary fate of slavery were elaborated, revised and repeated by abolitionists, manoeuvring as they were first against the slave trade and much later against the institution of slavery itself, we can begin to see the ways in which the resistance of the enslaved was a central concern for the abolitionists. They endlessly documented and catalogued and advertised such actions - the myriad of tactics and strategies such as slowing down, absconding, working in various forms outside the formal laws of enslavement, rebelling - in their efforts to prove that the institution was inefficient precisely because it made the enslaved recalcitrant.

In The Mighty Experiment, Drescher notes the negative impact of the Haitian 
revolution and the anti-slave trade debates on the abolitionists' willingness to use arguments about the economic rationality of 'free labour'. ${ }^{18}$ He points out that in 1802 James Stephen, "the "Saints" most informed and authoritative expert on the Caribbean', publically stated his 'clear conviction, that such cheapness of labour is by no means to be expected from the voluntary industry, however great, of negroes in a state of freedom, as now excites the enterprise and splendidly rewards the success of the planter, in places where slavery is established. ${ }^{19}$ Stephen made the statement in a lengthy pamphlet about the revolution in St. Domingue in 1802 but in the context of a discussion of the future development of Britain's recent imperial acquisition, Trinidad. Stephen's 'conviction' needs to be seen in the wider context of these plans insofar as they illustrate the terms in which he envisions a reformed labour system, and various roles that forcibly acquired Africans might play in the aid to the imperial wartime state.

Stephen reflects the benefits that will stem from banning the importation of enslaved Africans, and introducing new forms of labour management in the colony. He acknowledges that the dip in profits would be the chief objection to implementing his vision but notes that 'short-sighted avarice' would be replaced by the establishment of 'a firm and tranquil dominion' where planters' gains would be 'more uniform and infinitely more secure'. ${ }^{20}$ If a 'more liberal policy' was adopted, he argued, speculation would make the settlement prosper. Moreover, the extensive availability of land for provisioning, extremely fertile soils, with a particular amenity to new technology, would sustain a labour force that would become, via their wages, avid consumers of British goods, giving in turn a fillip to British shipping. ${ }^{21}$ Stephen's plan is founded, however, on indenturing the first 'free Negroes' within a heavily legalistic, metropolitan-based set of structures that would require Special 
Magistrates, the maintenance of a formal punishment system, wages to be determined by law, and banning of the whip. This nascent 'apprenticeship system' was to be installed precisely because 'that bane of moral character in the slave is utterly inconsistent with the happy formation of a new system, as well as with the effectual reformation of the old'. ${ }^{22}$ Enslaved Africans were 'ricketty infants' who must be 'taught how to walk'.23

Africans who had not yet experienced work under slave condition were understood to be suited to another sort of disciplinary regime. Stephen advocates the purchase of kidnapped Africans to replenish the military presence in the West Indies, arguing that their able-bodied nature, their 'yet unbroken spirit', and their attachment to the 'government that had redeemed them from captivity', would make them 'excellent defenders against the hostile attempts of France'. Of the 'fidelity' of 'armed negroes', he assures his readers, there can be no 'reasonable doubt; for the cause of Great Britain would be their own'. ${ }^{24}$ Stephen's lengthy justification for re-allocating of African labour via state-managed indentureships and direct purchase were made in the specific context of Britain's efforts against the French. They were rationalised in the name of a future economic prosperity but also with an eye to eliciting imperial identification and stability. The combination of indentured servitude and military impressment as appropriate alternative roles for Africans who would be otherwise enslaved would become part of the Act to abolish the British Slave Trade in 1807, also authored, in great part, by Stephen.

The 1807 Act legislated for the destiny of the Africans seized from illegally operating slave ships in the context of imperial war. They would be either enlisted into the British military forces, or indentured, as 'apprentices', for a maximum of fourteen years. ${ }^{25}$ These measures, or indeed the Africans themselves, were not 
represented in the celebratory memorabilia marking the humanitarian triumph of 1807. Perceptions of their fate, however, helped to shape the 'war of representation' being fought over different forms of labour in ways that became increasingly difficult for the parliamentary abolitionists to counter. ${ }^{26}$ The fact that the anti-slave trade legislation, and the administrative structures and practices of slave trading and slavery, were intimately related, consistently embarrassed the African Institution in the early years of suppression, eliciting sustained controversy in the colonies on both sides of the Atlantic and in London. ${ }^{27}$

The pro-slavery lobby opportunistically appropriated the radical attacks on the evangelical conservatism associated with the development of Sierra Leone to the point where parliamentary abolitionists had to admit the limitations of the Abolition Act. They stressed that the constraining terms of rescue had been devised as protective measures for the benefit of the Africans themselves. Their rationale had either to do with the African's 'ignorance', meaning that it had been 'necessary in respect of them to give for their own sakes the power of enlisting or apprenticing' or to prevent the possibility of re-enslavement once disembarked in the sugar colonies. ${ }^{28}$

Abolitionists were strangely silent about the thousands of Africans appropriated for the military during the Napoleonic wars, despite the fact that the policy had formed part of James Stephen's 1802 plan. ${ }^{29}$ By 1823, however, in a long pamphlet championing various exemplary instances of colonial improvement, Thomas Clarkson was explaining that the African soldiers, since 1819, when the regiments had been disbanded, had 'conducted themselves with great propriety' both in Sierra Leone and in the West Indies. The army, he argued, needed to be seen, therefore, as an ideal 'preparatory school'. Because the Africans were 'never out of reach of discipline', they had been 'fitted ... by degrees for making good use of their 
liberty' ${ }^{30}$

Before 1815 , the majority of captives returned to Sierra Leone or the West Indies were enlisted to fight for the imperial interest. Those deemed 'unfit' for military service were indentured, providing a new source of bound and disciplined labour for the colonies. This decision can also be traced to Stephen, and also Zacharay Macaulay. Macaulay had struggled with the original settlers of Sierra Leone as they refused to submit to the strict paternalist discipline required by company rule. ${ }^{31}$ The mobility of the settlers frustrated him more than anything else. He complained that it was 'impossible to subject them to regular instruction' unless some way of correcting their 'migratory habits' could be found. ${ }^{32}$ His experiences leant weight to the idea that some measure of 'constraint' should be written into the anti-slave-trade regulations. While Stephen, the other principle architect of the Bill, was concerned about the lack of detail and discrimination in the final document, Wilberforce defended the exploitative measures as 'the least objectionable way of rescuing slaves', a phrase that abolitionists would continue to use throughout the campaign when justifying the policy. $^{33}$

Perhaps it is unsurprising that the legal terms of rescue written into the Slave Trade Act drew a thin veil between enslavement and freedom but the language of the Act, and then the ways in which it was translated into action, provides a powerful example of the historical process by which those flimsy boundaries could be drawn and redrawn. The seizure of Africans trapped aboard privately-owned slave ships became possible legally by defining them as contraband commodities rather than as kidnapped or trafficked peoples. Rescued Africans were taken as slaves. In this way, they could be confiscated to become property of the Crown. Once 'condemned' as Prize by the Vice-Admiralty Courts, however, in no circumstances were they to be 
'sold, disposed of, treated or dealt with as Slaves'. Thus, the act of condemnation explicitly negated the Africans' status as illegally transported goods. Once impounded but not enslaved, officials were authorised to 'enlist the same, or any of them, into His Majesty's Land, or Sea Service, as Soldiers, Seamen, or Marines, or to bind the same or any of them, whether of full Age or not as Apprentices, for any Term not exceeding Fourteen Years'.

The language of the Act paid careful attention to way in which this recalibration of identity and condition was to be enacted. It demanded that the Africans enter into these new relationships 'as if' they had done so voluntarily. Equally, any African recruited into the military was to be treated 'as if he had voluntarily so enlisted' except that the associated provisions to limit the length of service, or to provide a pension on discharge, did not apply. ${ }^{34}$ The form in which the rescue process is dramatised as a procedural narrative tries to have it both ways to the point that it is not freely given 'consent' but rather its performance that glosses the imperial instrumentalism that structured the activity in the first place.

The 1808 Orders in Council added further practical guidance that drew boundaries in order to produce differentiated constituencies, and which further attempted to deal with the convergences between consent and coercion. Courts of Vice Admiralty were to be established at Freetown in Sierra Leone, and on several West Indian islands. Each colony's Collector of Customs - dealers in contraband was made responsible for administering the passage of the Africans into the armed forces or indentured servitude. If an African's name was 'unknown', or not 'sufficiently easy, clear, and distinctive', the Collectors were instructed to find another, and then to use that name thereafter until the individual was 'sufficiently instructed for baptism' whereupon that name would become official. ${ }^{35}$ Collectors 
were instructed to do their utmost to reunite family members 'except where the employment of either shall make such separation indispensible'. ${ }^{36}$ They were also instructed to assemble new families by encouraging those men enlisted to take rescued women as wives. These women would, insofar as it was possible, be permitted to live with their husbands, or to be indentured into domestic service nearby.

When arrangements aimed at rationalizing the process were made by establishing a 'recruiting depot' in Freetown in 1811, the popular metropolitan equation of military coercion with slavery, coupled with the Sierra Leone controversies, meant that it was 'highly necessary to bring the Military Service into repute by the encouragement of Voluntary Enlistment'. The encouragement took the form of using captives who spoke 'African languages' to 'explain the advantages attending the situation of a British soldier'. A form of contractual bargain was introduced insofar as a 'Bounty of Eight Guineas' was to be paid to those who were enlisted. This sum was just over half the standard amount of fifteen guineas given to white soldiers 'under the idea that such trifling articles of inducement more acceptable to the Negroes than Money, may be furnished. ${ }^{37}$ Amongst the items requested for export to Sierra Leone for this purpose were 200 small looking glasses, 200 pounds of Common Beads, 30 cwt. of tobacco and one thousand 'Snuff Boxes with a painted Portrait of a Black Soldier under Arms'.38

Africans deemed unfit for enlistment were to be indentured to 'prudent and humane masters and mistresses' who had a reputation for treating their slaves with 'humanity', to 'learn such trades, handicrafts, or employments as they may seem most fit for'. Women were to be employed as domestic servants and not 'the labours of Agriculture' (a euphemism for field work). Bound servants were to be provided with 
food, clothing, instructed in the Christian religion with a view to baptism, and permitted to attend church. Collectors were instructed to submit an annual report detailing all indentureships and their progress. If they were unable to produce an apprentice for inspection, they were liable for a fine: the amount payable would be equivalent to 'double the sum at which an apprentice would be valued if to be sold as a slave'. ${ }^{39}$

There was little interest in the kidnapped Africans who were being indentured in Caribbean until the controversies over the Registration Bills. In 1821, Wilberforce called for a Royal Commission of Inquiry to investigate the 'state' and 'condition' of these 'Captured Negroes' as the first indentures were reaching expiry and it was understood that rescued Africans were indeed being 'seduced away from their employment' in order to be sold as slaves. ${ }^{40}$ Given that the Abolition Act had not legislated for the period after the expiry of the indentures, the Commission's findings would help determine the direction of colonial policy. More generally, the question underpinning the inquiry was whether the rescued Africans supported the abolitionists' argument that Africans could, and indeed would, become civilised, colonial subjects willingly engaging in their labour.

The Commission lasted for over five years and accounted for over 3,000 kidnapped Africans in eight sugar colonies. ${ }^{41}$ While it is important to note that the findings do not relate directly to enslaved peoples in the colonies, the resulting mass of documents provide a vivid example of the ways in which political-economic considerations about labour discipline intensified and narrowed during the final phase of the anti-slavery campaigns. In particular, they illuminate the ways in which African identity came into question as a function of the need to know how to control a huge, racially identified, soon to be free, labour force. Significantly, the archive is not 
simply expressive of the white control fantasy but constitutes evidence of the attempted enactment of it. In this sense, these documents do not simply provide a commentary on what happened, they need to be seen as part of the historical process.

In the end, the assembled information was largely untranslatable into policy, despite its social scientific veneer, and its copious peripheral qualifications. In many ways, however, it is precisely the incoherent nature of the Commission that is most revealing insofar as it illuminates the discrepancies between abolitionism's idealised representations and their distorted material outcomes. As the sheer mass of accumulated documents attests, the investigative process was neither orderly nor consistent. In fact their most expressive quality lies in the ways in which they give the lie to the idea that the exertion of colonial surveillance functioned to immobilise and fix subjects. Multiple, minutely detailed, and endlessly qualified instances in which the rescued Africans actively refused to recognise the terms of their rescue disrupt the tables, statistics, and columns designed to organise and affirm authoritative information. Hundreds of indentured Africans explained to the Commissioners how they fashioned their own lives either through necessity or through the desire for independence. They repeatedly spoke back, arguing that they were treated like slaves even though they were not enslaved. They demanded to know why they received no wages for their work - a demand that was invariably recorded as insolence, or insubordination. In this sense, the Commission, despite itself, documents the Africans' own contributions to metropolitan debates about colonial subjecthood, servitude, and self-ownership. Their stories, or 'enforced narratives', forced comparisons between slavery and servitude, and the legal consequences of inhabiting one or other condition well before emancipation was even likely. ${ }^{42}$

It is impossible to offer an extensive analysis here, so the purpose of the 
following is to note how the desire for labour discipline actively produced highly contested understandings of colonial agency and aptitude. The documents provided evidence of the wide variety of bonded labouring contexts that existed within and alongside enslavement, and the imbrication of the imperial state in many of them, including Africans working as Crown slaves, military labourers or pioneers, hired out for gang labour by colonial Collectors, and indentured servants. Kidnapped Africans had been indentured amongst all strata of the free population, and were working in a wide variety of conditions both inside and outside of the plantation. Many had been put to fieldwork by planters accessing a new, and comparatively cheap, new source of labour. For example, while on Nevis the Commissioners found that George Forbes, one of the wealthiest planters, had taken twenty-nine apprenticed Africans, the majority of whom he had employed in 'cane-holing'. The imminent arrival of the Commissioners prompted him quickly to remove them from the field with later assurances that he would now be employing them as tradesmen and domestics. Planters justified their actions by suggesting that being put to fieldwork functioned as a punishment for unruly behaviour. For example, Forbes's indentured servant, John, was subjected to gang labour in the field because he had 'quarreled and fought' with staff in the house. ${ }^{43}$ Meanwhile, Wharton, employed as a cook in Antigua, whose 'honesty and sobriety' had been called into question, was 'sent into the country for improvement'. ${ }^{44}$

Indentured Africans also worked on plantation as house servants, or in maintenance work. Others worked small provision grounds, growing food for themselves as well as for their employers. Most servants lived in urban or semi-urban situations, working in menial service or domestic situations. The division of labour was explicitly gendered: all female apprentices were employed as house servants, 
cooks, washerwomen or seamstresses, while the men tended to work as porters, gardeners, or cleaners. Some were bound to coopers, carpenters, builders, cobblers or tailors, and others were employed as boatmen, fishermen, and mariners. The records show that when the indenture contract was with a tradesperson, often it did not include the training associated with an apprenticeship. Many Africans were engaged in such a variety of occupations both within and outside their contracts such that it was impossible to define their employment.

Wealthy colonials employed large numbers of the apprentices in their households, or hired them out, which could be very lucrative. ${ }^{45}$ Merchants employed them to work on the docks and in transportation. Others were apprenticed to the free black, petty trading population. For example, Myrtilla was indentured to George Dix, a merchant, but on his death was transferred to Joseph Harrington, a 'free coloured shoemaker'. ${ }^{46}$ Joan, also first indentured to Dix was had been transferred to Penelope Demming, 'free coloured woman, laundress and baker. ${ }^{47}$

Ascertaining the 'Actual Condition' of the Africans was inextricably linked to the Commissioners' judgment of character and attitude, and they had very different interpretations of what they heard and saw. Overall, however, the reports reveal the disciplinary atmosphere of the Commission process while also exposing the contingent, and coercive, social contexts within which indentured servants existed.

The attribution of 'idleness' was given to forms of conduct and behaviour that denoted an active refusal to submit to bonded service. Sustained attention to the mobility of the servants, many of whom absented themselves in search of temporary work, signalled a deep unease about a population unattached to employers and seemingly immune to time discipline. Whether it was by necessity or through the desire for independence, picking up casual work was invariably understood as 
disloyalty, and as a failure to accept rank.

The Africans had a variety of perceptions of the Commission. Some thought they were to be freed, and even those who had broken the terms of their indenture voluntarily appeared before the Commissioners. Others knew that, if they complained, their allegations would, or at least should, be investigated. For example, Forbes's Antigua-based servants knew they were not supposed to be working in the field, and used the inquiry to voice their complaints. Mingo stated that he did 'not like such work' and Goodluck took the opportunity to say that 'he would not work in the field with the hoe among the gang anymore'. ${ }^{48}$ As a result, colonials resented the arrival of the Commission, blaming it for their servants' bad behaviour. Elizabeth Graham believed that the it had caused her servant, Charlotte's, recent 'impertinence', which she thought had come from 'bad advice'. The record states that Charlotte was a tolerable good character, till latterly, when she told her mistress, that if she chastised her, she would come and complain to the commissioners. She infers, from what she had heard in the chapelyard, from three African apprentices who were there, that the gentlemen had come out to take them away, on their complaint against their owners ... ${ }^{49}$

Thomas, domestic to J.P. Doan, a merchant, came back from St. Thomas to see the Commissioners in Tortola. Doan said that Thomas had stated that he had returned 'to be made free', which Thomas later denied. Thomas told the examiners that many of his countrymen had run away to St. Thomas again after their examination. The Commission records that Thomas had been imprisoned for vagrancy on his return, and was brought straight from jail to the Commission. He appeared to be a 'violent and insubordinate character disposed to be insolent during his examination., 50 
In many ways, the aims of the Commission were contradictory from the beginning. The officers were asked to report on the 'state' and 'condition' of the kidnapped Africans, and also on whether they could support themselves after their indenture had expired. The evidence that might have confirmed that possibility, for example if some Africans were indeed working for themselves, was also a violation of the contract of indenture. Signs of self-interested and acquisitive agency, so desired by abolitionists and the Colonial Office alike, were nearly always recorded as signifying disobedience, insubordination, unreliability, vagrancy, or idleness; the enactment of willing labour 'elsewhere' and for personal gain were read as the rejection of dutiful servility, and ingratitude.

The final assessment of Major Thomas Moody, one of the first two Commissioners, stands out starkly from those of the other officers. Despite, or perhaps because of, his extreme position, his views had a significant impact in the metropole. As well as riling the abolitionists, Moody kept up a continuous dialogue with the Colonial Office, vigorously contesting the other reports verbally, by private correspondence, and in the papers. ${ }^{51} \mathrm{He}$ refused to submit a joint report with his colleague, and relative by marriage, John Dougan. Dougan, a West Indian who had close connections to the Clapham Sect, was determined to view the indentured Africans through the lens of redemptive abolitionism that combined economic advance, moral uplift and imperial identification. He determinedly portrayed the Africans as malleable colonial subjects, reporting that 'a desire to possess property of their own ha[d] been generally excited among them'. He expressed confidence that they would not rise up after they were released from their bonds because they would have a particular loyalty to the British greater even than manumitted slaves. He wrote optimistically, 'knowing the great ransom that has been paid for them, they must feel 
a greater obligation than those who have purchased their own freedom'. ${ }^{52}$

The second two Commissioners, Gannon and Bowles, had also disagreed to the point of violence between them. ${ }^{53}$ Gannon submitted his own report in which he took a more utilitarian approach to the issue of voluntary labour. He viewed the Africans as persons who "could acquire their livelihood ... by their own industry and good conduct if no obstacles were to be placed in the way of their exertions'. Referencing his experience in Antigua, he criticised the institutional arrangements for housing unplaced or unbonded Africans. The 'Hospital Establishments' hindered the 'moral progress' of the Africans because they were hired out in 'irregular gangs' which prevented the development of 'habits of regular or useful industry'. ${ }^{54}$ Gannon also observed that it was remarkable that 'all those Africans whose apprenticeships had terminated, preferred the privileges of being allowed to seek their own subsistence, to remaining any longer in the service of their masters and mistresses.' He glossed the observation, however, by assuming that they would not do so for long if 'freedom' was accompanied with a 'precarious mode of living'. ${ }^{55}$

The third set of Commissioners examined a small group of indentured servants in Demerara, the majority of whom were Barbadians who had been illegally imported into the colony. Like all the other Commissioners, Burdett and Kinchella acknowledged that the servants would not work voluntarily in agriculture, 'the most laborious of all occupations'. In their view the creoles were much improved by their 'constant intercourse with Europeans'. For the servants themselves, their terms of service or employment were far less important than their 'strong desire' to be returned to Barbados in order to be reunited with their families. ${ }^{56}$

Major Moody submitted two reports, each of which ran to hundreds of pages ${ }^{57} \mathrm{He}$ had a 'philosophy of labour' through which he saw himself as a 'practical 
philanthropist'. ${ }^{58}$ Deploying his knowledge of engineering and colonial surveying, indebted historically to the vicious, and colonially applied, 'political arithmetic' of William Petty, Moody took the opportunity not only to attack the abolitionists' naiveté over the future of the plantations but to offer his own remedies.

Moody was well versed in abolitionist literature, noting that Stephen's recommendation of a period of indenture in 1802 had been reworked for the Act for the Abolition of the Slave Trade, and for the Orders in Council. ${ }^{59} \mathrm{He}$ believed that the scheme had been irredeemably flawed in dictating that rescued Africans, who were 'in a backward state of knowledge', be exempt from plantation labour. ${ }^{60} \mathrm{He}$ argued from the basis of the 'physical fact' that only blacks were suited to hard agricultural labour in the 'torrid zone', and that the pressing issue was how 'capitalists' would be able to extract 'steady' and 'continuous labour' if not under conditions of enslavement. ${ }^{61}$ Moody endlessly reiterated the fundamental necessity of 'some degree of coercion' to ensure 'steadiness'. ${ }^{62} \mathrm{He}$ argued that many of the problems in Tortola (where he had been a Commissioner) stemmed from the fact that the island was too poor to afford a police force, or a treadmill. Moody's solution to the problem of West Indian labour combined eighteenth century climatological theory, Scottish Enlightenment theories of history, and the scientific theories of modern physics. He was enamoured with Charles-Augustin de Coulomb, who, in his early career, had been a military engineer in Martinique, in charge of thousands of African slaves who were employed in building the island's fortifications. ${ }^{63}$ Today, Coulomb is remembered for lending his name to a measure of electric charge. It is less noted that he also used his colonial experience to develop a scientific theory of human labour power, defining 'work' as 'the product of thrust multiplied by the speed and length of the effort exerted'.64 
Moody had studied a wide variety of projects that utilised coerced labour. He was fascinated by post-revolutionary Haiti's labour codes set out by Toussaint and Christophe, and in President Boyer's 1818 invitation to freed African Americans to emigrate to Haiti under certain stipulations. ${ }^{65}$ He thought Johannes van den Bosch's Dutch agricultural colonies for the criminalised poor might provide a model for the West Indies, although he was troubled by Bosch's inattention to religious instruction, as it 'was necessary to have some strong moral power over [the labourer's] mind' ${ }^{66}$

Moody's plans reflected the understanding of the valuation of people understood only in terms of their labour power first developed as early modern political arithmetic and that understanding could also be extracted, and abstracted, from the general thrust of contemporary political economy. If human value was calibrated in this way then people were eminently portable thus signalling the relations between contemporary emigration and indenture schemes, convict transportation, and colonial production as Clare Anderson argues in her chapter. Moody advised that the indentured Africans be extracted from the colonies, and taken back to West Africa, suggesting that an island off the coast would be most appropriate setting. He reasoned that an island, 'and particularly a small one, renders it more difficult for any of the inhabitants clandestinely to withdraw themselves in the first stage of their cultivation'. ${ }^{67}$ The plan was a way to ensure that the rescued African would be 'forced to experience the advantages resulting from the enjoyment of wealth to be created by his own labour' ${ }^{68}$

Moody's crude theorising was bizarrely constructed by layering random scholarly reference upon reference as if this method would somehow secure his argument. Nevertheless, his yoking together of racial hatred, instrumental reasoning, and the assumed authority of long years of military experience in the West Indies, 
meant that his thinking did not fall on deaf ears. Bathurst was interested in Moody's ideas but knew that they were incendiary. Bathurst's under secretary, Wilmot Horton, had sympathy with the racial basis of Moody's plans, as is clear in their extensive private correspondence about the indentured Africans. Moody was not a member of the intellectual elite but he was able to move between factions of the establishment due to his military standing and colonial experience. He was a member of London's new Political Economy Club, arguing his cause with Mill, disagreeing with McCulloch, and impressed by Jean-Baptiste Say’s commitment to facts. ${ }^{69}$ Moody insisted that one had to argue from local experience, and the problem with political economy was its focus on production rather than on the specificities of labour. As he complained to Horton, 'All have followed Adam Smith's assumption that the desire to

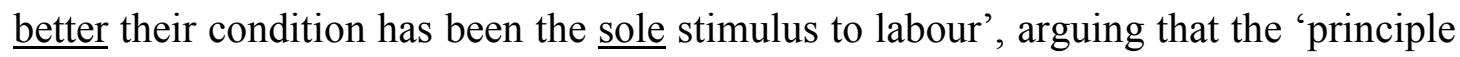
of necessity' acts universally on all men but the 'desire of bettering one's own condition' requires much more careful consideration that required an attention to 'local, physical, and moral nature'. ${ }^{70}$

Moody's ideas about the necessity of coercion if labour was to be 'steady', 'regular' and ordered were not, of course, novel, although his method of reaching them was bizarre. The problem of producing the self-discipline required by a free wage labour economy was a key issue for early nineteenth century reformist governance both at home as well as in the colonies. ${ }^{71}$ The ability of theoretical political economy to accomplish its scientific ends always required an attention to the specificities of cultural reproduction despite its claims to universalism. That the failure to conform to the requirements of free labour should elicit new 'scientific' narratives of racial as well as cultural inadequacy is well established but most often attributed to the post-emancipation period in the Caribbean, and to Ireland. Horton, 
who was deeply interested in political economy, listened carefully to Moody. In 1824, he sent one of Moody's papers to Canning writing,

...it is not to be forgotten that the nature of the African is to be indolent inasmuch as his wants are few and those almost spontaneously satisfied in the climate under which he lives - No adage can be more trite in political economy than that which points out the connection of Exertion with Climate \& which would enable a person " a priori” to pronounce in the probable industry of a nation from the mere knowledge of that physical circumstance. This condition would necessarily be modified by density of population, circumstances of civilization but still the principle is true and valuable. ${ }^{72}$

Moody's plan to expropriate the Africans once again, and to return them to a remote island off the West coast of Africa, was not enacted. In October 1828, colonial governors were directed to issue certificates of freedom to all Africans no longer, or not, indentured. These certificates still contained the stick of coercion and the threat of criminal prosecution if labour expectations were not met. For a further seven years the right to remain in place was secure as long as the bearer's 'Conduct merits this Indulgence'. If found to have engaged in criminal activity, or simply become dependent on poor relief, 'free' Africans were liable to be transported, and to be 'constrained to labour for [their] Subsistence'. ${ }^{73}$

The Commission records are not an archive that commemorates the enslaved but it is one that documents something of the experience of unenslaved 'captives' forced to inhabit in a slave society. Ironically, their significance might lie precisely in the fact that they have been almost entirely ignored. Royal Commissions traditionally take privileged positions in shaping received historical chronologies, in crystallising 
the significance of certain events or conjunctures, and in monumentalising the imperial past but this one has no place in the scholarship to date. It is not simply the constraints of narrative form that ensures that historical outcomes, and only certain outcomes, are deemed to be more important than an examination of the historical processes through which they are produced.

Assimilating the kidnapped Africans stranded in the Caribbean in the late 1820 s, neither enslaved nor free, into the powerful story that insists that all history is written as a prelude to freedom might ensure that they become, at least, footnotes, or at best intermediaries. Yet, they also disrupt that story by drawing attention to a deeper set of historical continuities and convergences in a wider imperial reallocation of colonial labour within which Caribbean emancipation was implicated but which it did not completely define. As David Lloyd argues in another context, 'for the materialist cultural historian, the actual outcome of multiple social vectors is less important than the swirling eddies of possibility out of which that outcome emerged'. ${ }^{74}$ The 1821 Commission registers a significant moment in slavery's undoing, illuminating the continuing and uneven imbrication of the extraordinarily powerful discourses of moral sentiment and political economy in the effort to configure alternatives to colonial enslavement. The fact that the abolitionists kept the ideal of 'free labour' in view needs to be acknowledged at the same time as subjecting the concept to critical historical analyses that highlight its ideological interests and political investments. The Commission records discussed here offer an insight into the construction of a modern racialised division of labour, of which slavery was a momentous part, that shaped, and continues to shape, the ongoing violence associated with imperial power today.

Despite all the evidence elicited by this Commission, the 1807 Act to Abolish 
the Slave Trade resurrected an ancient form of bonded labour contract (that had preceded Caribbean enslavement) that came to pass for the 'emancipation' of all the enslaved in 1833 and which would be extended to capture other colonial constituencies thereafter. Tens of thousands of 'Liberated Africans' continued to be shipped across the Atlantic, as indentured servants, to replenish the plantations until the 1860s. Both of these episodes allude to the ruptures and continuities that render this history incomplete. Finally, however important it is to acknowledge the centrality of political economy to the shaping of the 1833 emancipation - Richard Madden insisted, by this time, its terms could be understood as a form of 'common sense' - the intensity of interest in labour management, discipline, and efficiency formulas is a reminder of the extent to which the categories that emerged from the economic imperative could only develop due to an enormous blind-spot in metropolitan thought. That the ideas, desires, and motives of Africans and their descendants were themselves elements in the historical process was unconscionable for both slaveholders and their critics. It is precisely because these elements were repressed, those with power were able to invent extraordinarily durable ideas about the sovereign power of the market, the waged character of free labour, and about how one calibrates racial or cultural inadequacy all of which have taken on an even harder veneer in the contemporary neoliberal order.

The issue such silence, of what is not there, has functioned as a powerful postcolonial anchor around which to engage the problems of excavating an archive shaped by the developers of political economy. But perhaps we should be wary of giving it too much space given the bureaucratic assiduousness of Britain's imperial machine. To reiterate a point made earlier, the Commission records addressed here do not commemorate slavery, and they only came into being through imperial efforts to 
find a script for the end of slavery. They bear witness, however, to the fact that forcibly transported Africans arriving in the Caribbean prior to 1833, under the auspices of the British Navy rather than the slave traders, represented their own lives, and figured freedom in ways that pointed beyond, beside, and outside the confines of those incarcerating narratives. 
${ }^{1}$ Richard Robert Madden, A Twelvemonth Residence in the West Indies during the Transition from Slavery to Apprenticeship, Vol. II, (Philadelphia, 1835), pp. 23-4.

${ }^{2}$ Mathew Gregory Lewis, Journal of a West India Proprietor kept during a residence in the island of Jamaica (London, 1834).

${ }^{3}$ For the role of political economy in formulating the terms of the Emancipation Act see Thomas C. Holt, The Problem of Freedom: Race, Labour and Politics in Jamaica and Britain, 1832-1838 (Baltimore and London, 1992), pp. 33-53.

${ }^{4}$ Michael Guenther, 'A peculiar silence: The Scottish Enlightenment, political economy, and the early American debates over slavery', Atlantic Studies, 8:4 (2011), 447-483; Robbie Shilliam, 'Forget English Freedom, Remember Atlantic Slavery: Common Law, Commercial Law and the Significance of Slavery for Political Economy', New Political Economy, 17:5 (2012), 591-609.

${ }^{5}$ Walter Johnson, 'The Pedestal and the Veil: Rethinking the Capitalism/Slavery Question', Journal of the Early Republic, 24 (Summer 2004), 299-308, p. 300.

${ }^{6}$ Seymour Drescher, The Mighty Experiment: Free Labour versus Slavery in British Emancipation (Oxford, 2002).

${ }^{7}$ Adam Smith, The Wealth of Nations (London, 1991), p. 72.

${ }^{8}$ David Kazanjian discusses Smith's strident critique of the sentimentally unstable 'non-national' merchant in the Wealth of Nations in The Colonising Trick: National Culture and Imperial Citizenship in Early America (Minneapolis, 2003), pp. 76-77. ${ }^{9}$ Smith, Wealth of Nations, p. 548.

${ }^{10}$ Christopher Leslie Brown, Moral Capital: Foundations of British Abolitionism (Chapel Hill, 2006), pp. 209-58.

${ }^{11}$ James Ramsey, An Inquiry into the Effects of Putting a Stop to the African Slave 
Trade (London, 1784), p. 6. Cited in David Beck Ryden, West Indian Slavery and

British Abolition, 1783-1807 (Cambridge, 2009), p. 168.

${ }^{12}$ Ryden, West Indian Slavery, p. 168.

${ }^{13}$ Thomas Clarkson, An Essay on the Impolicy of the African Slave Trade (London, 1788).

${ }^{14}$ Shilliam, 'Forget English Freedom', 601.

${ }^{15}$ See Adam Smith's discussion of the relations between slave labour, 'good management', and political order in The Wealth of Nations, pp. 523-4.

${ }^{16}$ Drescher, Mighty Experiment, p. 46.

${ }^{17}$ Walter Johnson, 'Commentary', in Winthrop D. Jordan, (ed.), Slavery and the American South (Jackson, 2003), p. 54.

${ }^{18}$ Drescher, Mighty Experiment, p. 109.

${ }^{19}$ James Stephen, The Crisis of the Sugar Colonies (London, 1802), p. 191.

${ }^{20}$ Ibid., p. 185.

${ }^{21}$ Ibid., p. 192-3.

${ }^{22}$ Ibid., p. 188.

${ }^{23}$ Ibid., p. 56.

${ }^{24}$ Ibid., p. 196-7.

${ }^{25}$ Johnson U. J. Asiegbu, Slavery and the Politics of Liberation, 1787-1861: A Study of Liberated African Emigration and British Anti-Slavery Policy, (London, 1969), pp. 1-33; Howard Johnson, 'The Liberated Africans in the Bahamas', Immigrants and Minorities, 7:1 (1988), 16-40; Alvin O. Thompson, “African "Recaptives" under Apprenticeship in the British West Indies, 1807-1828, Immigrants and Minorities, 9:2 (1990), 123-44; Rosanne Adderley, "New Negroes from Africa”: Slave Trade Abolition and Free African Settlement in the Nineteenth Century Caribbean, 
(Indianapolis, 2006).

${ }^{26}$ Catherine Hall, Civilising Subjects: Metropole and Colony in the English

Imagination, 1830-1867, (London, 2002), pp. 107-14.

${ }^{27}$ Michael J. Turner, 'The Limits of Abolition: Government, Saints and the "African

Question”, c. 1780-1820', The English Historical Review, 112:446 (1997), 319-57;

Tara Helfman, 'The Court of Vice Admiralty at Sierra Leone and the Abolition of the West African Slave Trade, The Yale Law Journal, 115 (2006), 1122-56.

${ }^{28}$ For the former see James Stephen to Earl of Liverpool, 11 July, 1811. The National Archives [hereafter TNA], CO 23/85. For the latter see Anon., An Exposure of Some of the Numerous Misstatements and Misrepresentations contained in a pamphlet commonly known by the name of Mr. Marryatt's Pamphlet ..., (London, 1816), pp. 810.

${ }^{29}$ Buckley estimates that some 13,400 Africans, or $7 \%$ of all Africans arriving in the West Indies, were purchased by the British armed forces between 1795 and 1808 with the rate of purchase intensifying in 1806 as abolition became inevitable. Roger Norman Buckley, Slaves in Red Coats: The British West India Regiments, 1795-1815, (New Haven and London, 1979), 130-139.

${ }^{30}$ Thomas Clarkson, Thoughts on the Necessity of Improving the Condition of the Slaves in the British Colonies, with a View to their Ultimate Emancipation; and on the Practicality, Safety and the Advantages of the Latter Measure (London, 1823), p. 17.

${ }^{31}$ Cassandra Pybus, “"A Less Favourable Specimen”: The Abolitionist Response to Self-Emancipated Slaves in Sierra Leone, 1793-1808', Parliamentary History (2007), $100-14$

${ }^{32}$ Zachary Macaulay, 'A Letter to His Royal Highness the Duke of Gloucester', 
(London: Ellerton \& Henderson, 1815) Appendix 1, p. 3.

${ }^{33}$ James Stephen to Earl of Liverpool, 11 July, 1811. TNA, CO 23/85; Wilberforce to Thompson, 19 October, 1808. Cited in Pybus, 'Less Favourable Specimen', 110.

${ }^{34} 47$ Geo III Sess.2, c. 44.

35 'Abstract of the Acts of Parliament for Abolishing the Slave Trade, and of the Orders in Council Founded on Them', (London, African Institution, 1810), p. 35. 36 'Abstract', p. 34.

${ }^{37}$ H. Torrens to W. Merry, 1 November 1811 in (Slave trade.) Further papers relating to captured negroes enlisted, and to the recruiting of negro soldiers in Africa, for the West India regiments, Parliamentary Papers [hereafter PP] 1813-14; (356) XII, p. 9. ${ }^{38}$ PP 1813-14 (356) XII, p. 6.

39 'Abstract', p. 40.

40 'A Review of the Colonial Slave Registration Acts, in a Report of a Committee of the Board of Directors of the African Institution made on $22^{\text {nd }}$ February, 1820', (London, 1820), p. 63. James Stephen, 'Reasons for Establishing a Registry of Slaves in the British Colonies', (1815), p. 62.

${ }^{41}$ TNA, CO 320/5. The first Commissioners were John Dougan and Major Thomas Moody who travelled to Barbados and Tortola. In 1824, Commissioners Bowles and Gannon were appointed to go to Nevis, St. Kitts and Antigua, and Wyndham, Burdett and Kinchela were appointed to Demerara and to investigate the Winkel Establishment of Crown Slaves at Berbice. See Alvin O. Thompson, Profitable Servants: Crown Slaves in Berbice, Guyana 1803-1831 (Barbados, 2002), pp. 113-14. For the primary documents for the entire Commission see TNA, CO 318/82-3; CO318/85-93.

${ }^{42}$ Carolyn Steedman, Dust (Manchester, 2001), p, 54. Steedman uses the phrase in a 
discussion of the ways in which Magistrates demanded Poor Law claimants to tell their stories.

${ }^{43}$ T.H. Bowles and J.P. Gannon, 'Report concerning African Apprentices residing in the Island of Nevis, February 13 1824', PP 1826-7 (463) XXII, p. 36.

44 'Mr. Gannon's Report on the State and Condition of the Apprenticed Africans at Antigua', PP 1826-7 (355) XXII, p. 17.

${ }^{45}$ TNA CO 318/82.

${ }^{46}$ PP 1825 (114) XXV, No. 1, 'Schedules', p. 168-9.

${ }^{47}$ PP 1825 (114) XXV, No. 1, 'Schedules', p. 164.

${ }^{48}$ PP 1826-7 (355) XXII, No. 1, 'Schedules', p. 33.

${ }^{49}$ PP 1825 (114) XXV, No. 1, 'Schedules', p. 298.

${ }^{50}$ PP 1825 (114) XXV, No. 1, 'Schedules', p. 140.

${ }^{51}$ See The Antislavery Monthly Reporter, No. 15, pp. 216-219, No. 18, pp. 262-264, No. 19, pp. 271-277, no. 24, pp. 386-387, in The Anti-Slavery Reporter (London, 1827); Morning Chronicle, 7, 15, and 20 September 1826.

${ }^{52}$ PP 1825 (114) XXV, No. 2, 'John Dougan's Separate Report', p. 20.

${ }^{53}$ John Wesley, 'The Neglected Period of Emancipation in Great Britain' 1807-1823', The Journal of Negro History 17:2 (1932), 156-179, p. 175.

54 'Second Separate report of Mr. Gannon', PP 1826-27 (463) XXII, p. 59

55 'Mr. Gannon’s Report' (Antigua), PP 1826-7 (355) XXII, p. 39.

${ }^{56}$ PP 1826-27 (464), XXII, 'Report of Sir C.W. Burdett and Mr. Kinchella on the Captured Negroes at Demerara', p. 4

${ }^{57}$ PP 1825 (114) XXV, No. 3, 'Major Thomas Moody's Separate Report' and Reports by Commissioners of Inquiry into State of Africans apprenticed in West Indies: Part II. of Major Moody’s Report on Captured Negroes, 1826 (81) XXVII. 
${ }^{58}$ PP 1826 (81) XXVII, p. 19.

${ }^{59}$ Moody to Horton, July 23, 1822, Derbyshire County Records, (hereafter DCR), D3155/WH2835.

${ }^{60}$ PP 1826 (81) XXVII, p. 14.

${ }^{61}$ PP 1826 (81) XXVII, p. 66.

${ }^{62}$ PP 1826 (81) XXVII, p. 46.

${ }^{63}$ For Moody on Montesquieu PP 1826 (81) XXVII, p. 13; for Robertson see pp. 60, 75; for Coulomb see PP 1825 (114) XXV, No. 3, p. 120-121.

${ }^{64}$ For Coulomb's experiments in the mechanics of human labour see Antoine Picon, 'The engineer as judge: engineering analysis and political economy in eighteenth century France', Engineering Studies, 1:1 (2009), 19-34.

${ }^{65}$ PP 1826 (81) XXVII, pp. 28-56.

${ }^{66}$ PP 1826 (81) XXVII, p. 86. For further analysis of how van den Bosch developed penal settlements in order to cultivate appropriate free wage labour attitudes, and then exported them to the colonies, see Albert Schrawers, 'The "Benevolent" Colonies of Johannes van den Bosch: Continuities in the Administration of Poverty in the Netherlands and Indonesia', Comparative Studies in Society and History, 43:2 (2001), 298-328.

${ }^{67}$ PP 1826 (81) XXVII, p. 84.

${ }^{68}$ PP 1826 (81) XXVII, p. 85.

${ }^{69}$ Moody to Horton, May 22 1825; Moody to Horton, August 18, 1825, Moody to Horton, undated. DCR, D3155/WH 2835.

${ }^{70}$ Moody to Horton, August 18 1825. Ibid.

${ }^{71}$ For a discussion of the relationship between slavery and the discourse of labour management in early industrial England, see David Brion Davis, The Problem of 
Slavery in the Age of Revolution, 1770-1823 (Ithaca, 1975), pp. 455-68.

${ }^{72}$ Horton to Canning, 26 January 1824. DCR, D3155/WH2940.

${ }^{73}$ Thompson, Profitable Servants, p. 150.

${ }^{74}$ David Lloyd, 'The Political Economy of the Potato', Nineteenth Century Contexts, $29: 2 \& 3$ (2007), 314. 